\title{
Antecedents Influencing the Adoption of Collaborative Learning Social-Media Platforms Among Thai University Students During the Covid-19 'New Normal' Era
}

\author{
https://doi.org/10.3991/ijet.v16i13.18083 \\ Thadathibesra Phuthong \\ Silpakorn University, Phetchaburi, Thailand \\ thadathibes@ms.su.ac.th
}

\begin{abstract}
There are benefits and challenges related to the recent worldwide Covid-19-driven surge of social-media collaborative learning in higher education. This research examines the antecedents influencing this 'new normal' phenomenon among university students to provide a causal model of understanding. This study was based on a purposive sample; a questionnaire was completed by 371 university students. The analysis of the data obtained using applied structural equation modelling of the partial least-squares technique, it was found that the most influential antecedents included collaborative capability and perceived enjoyment. Based on the results, we recommend that, owing to the turbulent and changing requirements of social distancing and distance learning, educational institutions and stakeholders invest in the improvement of implied social-media collaboration and learning platforms.
\end{abstract}

Keywords - Antecedents, collaborative learning, social-media platforms, new normal

\section{$1 \quad$ Introduction}

Since the World Health Organization (WHO) officially codified the type-2 severe acute respiratory syndrome coronavirus as the 'COVID-19' disease in February 2020 [1], the pandemic has spread to all corners of the world, exerting shocking and sometimes catastrophic impacts to people from all walks of life. Thailand is not exempted from this turmoil. The Kingdom's first outbreak spawned from a Lumpinee Boxing Stadium event on March 6, 2020 and an infection from Thai nationals returning from their pilgrimages to Malaysia and Indonesia during the same year [2]. To contain the pandemic, the government declared an emergency decree on March 24, 2020 that detailed several restrictions, such as confining citizens to their residences during specified periods, blocking departures from ports of exit and prohibiting travel across provinces. Numerous directives pertaining to social distancing and the suspension certain business operations and services were also promulgated [2].

After the first COVID-19 wave subsided in June, 2020, several sectors of society began to talk about the 'new normal', a term coined by the Royal Society of Thailand pertaining to the new lifestyle restrictions, under which many pre-existing, familiar and predictable conventions and practices were replaced by new, unfamiliar and 
sometimes unpredictable ones [3, 4]. The 'new normal' lifestyle encompasses patterns of thought, learning, communications and organizational management techniques that are adapted more for human survival rather than maintaining the status quo of tradition [5].

COVID-19 is radically transforming education sectors worldwide. After extensive closures, institutions have adopted various methods of remote online education. Consequently, policymakers, administrators, teachers, and learners implemented online learning formats and cloud computing systems in their learning contexts. It has been predicted that, after the pandemic, remote and collaborative learning technology methods will become the 'new normal' in Thai education. Thus, attention should be paid now regarding how to ensure that this 'new normal' will provide desirable educational outcomes [6].

Collaborative learning approaches are based on the idea that the synergy gained from collaboration will result in greater educational achievement. It is a new approach in which learners sharing mutual interests can exchange their experiences and ideas, offering constructive feedback to one another and taking collective responsibility rather than competing in order to create, solve and decide on solutions as a team. This is being facilitated by advances in information and communication technology [7], such as the application of social-media platforms for information exchange and collaborative learning [8-11]. These methods have been effective worldwide in enabling two-way interactions among teachers, learners and partners anywhere and anytime [12].

In the context of Thailand, however, little research has been conducted to examine the application of social-media platforms for collaborative learning. A search of Thai Journals Online over a period of 10 years from 2010 to 2019 using the keyword 'social media' with 'collaborative learning' yielded very few directly relevant results, especially those relating to tertiary education. Therefore, to help fill this research gap, we wish to develop an understanding of the application of social-media platforms for collaborative learning in tertiary education during this 'new normal' era. The present study provides a model for determining the linkage between the factors involved in this vision and to solve related problems using a causal relationship approach. It is expected that the findings will benefit educational institutions at the tertiary level, as well as related authorities involved in the pursuit of online instructional management. It is ultimately desired that the application of social-media platforms for collaborative learning will become more widespread in the aftermath of COVID-19, which will necessitate new approaches to instructional management, including the provision of distance education through online systems, advanced information and communication technologies and more efficient social-media platforms.

\subsection{Research questions}

1. What are the factors influencing the adoption of social-media platforms for collaborative learning among Thai university students during the 'new normal' era?

2. What are the causal relationships of the factors influencing the adoption of socialmedia platforms for collaborative learning among Thai university students during the 'new normal' era? 


\subsection{Research objectives}

1. To examine the factors influencing the adoption of social media platforms for collaborative learning among Thai university students during the new 'normal era'.

2. To examine the causal relationships of the factors influencing the adoption of social media platforms for collaborative learning among Thai university students during the 'new normal' era.

\section{$2 \quad$ Literature Review}

\subsection{Collaborative Learning $(\mathrm{CL})$}

There are many researches studied about collaborative learning (CL) and its applications. Refer to Laal and Ghodsi [75], a collaboration is an interaction among individuals who are not only responsible for their learning but also respect the abilities and contributions of their peers. In terms of educational context, collaborative learning is an approach focusing on groups of learners at various performance levels who work together to achieve a common goal, similar to Khadka, Money, and Banic [77], such as solving a problem, completing a task, or creating a product. One the contrary, the competition to find the best individuals among others is not preferred. Moreover, Shih and Yang [76] studied a Collaborative Virtual Environment (CVE) in language learning and described CL as an environment in which learners are allowed and encouraged to interact and give one another support with their learning. It also takes learner profiles, objects, and the learning world into account.

According to Anderson [78], CL is used to support social presence and make the environment that students feel comfortable and safe to express their opinions. With a low degree of social presence, the students are unable to share disagreements and viewpoints and do not want to accept support from peers and teachers. Moreover, CL supports a teaching presence which is the design of learning experience both before and during the learning process. It helps a teacher to implement suitable activities among groups of students and enhance the role of teaching to be more than just moderating the classes since the students can participate to contribute their own skills to the learning communities as well.

The benefits of collaborative learning are various. Laal and Ghodsi [75] mentioned that CL leads people to know each other and extend their activities outside of class when they continue communicating later. Moreover, CL encourages diverse relationships and understanding as the learners are allowed to engage in personal and build meaningful learning through collaboration [76] which lead to the development of high levels of thinking skills [75]. It also develops communication skills of learners and self-management. CL allows teachers to observe the engagement of the students and the way they interact with questions, solve problems and discuss their ideas which lead to the development of more inclusive assessment [75].

Collaborative learning can be used in several contexts. According to Shih and Yang [76], a Collaborative Virtual Environment (CVE) can be applied with language learning. In the study, CL is integrated to help Taiwanese students improve learning English and develop communicative competence through a CL tool called VEC3D. It 
is a 3D interactive learning environment based on the principles of constructivist learning design, collaborative learning, communicative language teaching and goalbased scenarios which encourage students to interact and support others with their language learning. The study found that virtual communities with interaction/collaboration are related to the success of English communication. In addition, another study [77] also supports the fact that collaborative virtual environments encourage the learners to work together in a shared environment. In this context, research scientists who use multiple types of visualizations and platforms can collaborate to enhance scientific workflow which lead to unique analysis and discovery.

Moreover, CL can be used in online learning contexts [78]. Though it is very challenging to build collaborative learning when students are at different places in online learning, many institutions including Athabasca University are developing both realtime synchronous and asynchronous technologies to serve the learning preferences and needs and also enhance the effectiveness of learning. Furthermore, collaboration among and between students and teachers is a key for productive learning. Online learning then allows the teacher to build in video or presentations to enhance their presence to the learners.

According to the reviews mentioned above, collaborative learning (CL) is very important to enhance and support the learning community of the students. Nowadays, CL takes a role an effective educational approach to motivate the learners who study from different places. It can also be integrated in online platform to build comfort environment for students to participate actively.

\section{Development of the Conceptual Framework and the Research Hypotheses}

To develop the conceptual frameworks for examining the factors influencing the adoption of social-media platforms for collaborative learning among Thai university students during the new normal era, Davis's [13] technology-acceptance model (TAM) and Curtis et al.'s [14] unified theory of acceptance and use of technology (UTAUT) were employed. According to their frameworks, influential factors include key stakeholders' perceptions, perceived usefulness, perceived enjoyment, information and resource-sharing capability, team-working ability and the adoption of social-media platforms for collaborative learning. The details are presented in the following sections.

\subsection{Technology-Acceptance Model (TAM)}

Built upon Fishbein and Ajzen's [15] theory of reasoned action, the TAM postulates that users will accept a certain technology only when the factors that affect their decision to accept such a technology are existent. The model focuses on examining the factors influencing information technology behavioural intention. These factors are external variables, perceived usefulness and perceived ease of use. External variables refer to contextual factors influencing the perceived usefulness and the perceived ease-of-use of a technology. They are sometimes based on demographic characteristics and previous experiences. Next, perceived usefulness refers to the extent to which 
individuals perceive the usefulness of a certain technology in enhancing their job performance [13]. Finally, perceived ease of use refers to the degree of effort and complexity that individuals perceive as being involved in the use of a certain technology [13].

\subsection{Unified Theory of Acceptance and Use of Technology (UTAUT)}

First proposed by Venkatesh et al. [16], UTAUT draws on various models that examine users' acceptance of technology to ensure a comprehensive coverage of perspectives. Venkatesh et al. claimed that it could explain variance by as much as $70 \%$ [17]. As a result, it has been widely accepted and applied in several research contexts, such as studies investigating the acceptance of electronic and mobile health applications [18]. The tenet behind their theory is that users' intentions to accept and use a certain technology results from three constructs: performance expectancy (PE), referring to users' belief that the technology will be able to enhance their job performance; effort expectancy (EE), referring to the perceived ease of use of the technology; and social influence (SI), referring to the social determinant of behavioural intention (BI) and the actual use behaviour.

\subsection{Development of the research hypotheses}

Perceived critical mass refers to situations in which users form perceptions based on others who influence their thoughts, decision-making and world views, such as friends, classmates and social contacts. These people, in some instances, may exert more persuasive power than their family members. As a result, should the user perceive those groups as accepting of their use of social-media platforms for learning and professional collaboration, they will be more likely to also favour the practice itself [19, 20, 21, 22, 23, 24]. Sanchez et al. [25] and Čičević et al. [26] similarly found that the acceptance of social-media platforms for communication and learning collaboration among students resulted from their awareness of the acceptance of their influencers. Additionally, Milosevic et al. [27] and Ifinedo [28] reported that the perceptions formed based on influencers had a positive correlation with students' acceptance and use of social-media platforms for collaborative learning in their virtual classrooms. Based on these findings, our first hypothesis is formed as follows:

H1: Users' perception of critical mass will have a positive correlation with their adoption of social-media platforms for collaborative learning.

Perceived usefulness: Refers to the extent to which individuals perceive the utility of a certain technology in enhancing their job performance. That is, individuals are often able to roughly estimate how the technology will help them perform their jobs better [13]. According to TAM theories, perceived usefulness has a direct impact not only on users' attitudes towards their use of technology [29], but also on their technology acceptance behaviours [30]. In this study, perceived usefulness is defined as users' perception of the utility of social-media platforms for collaborative learning that engenders their intention to use them. Numerous studies have reported positive correlations between users' perceived usefulness of social-media websites and their decisions to use them [21, 31, 32, 33, 34, 35]. Mazman and Usluel [36], Lin et al. [37] and Lee and Chong [38] discovered that perceived usefulness helped determine users' 
acceptance of social-media platforms for collaborative learning. Chen and Tseng [39], Sanchez et al. [25], Ainin et al. [40] and Elkaseh et al. [35] went a step further, revealing that perceived usefulness had a significantly positive correlation not only with users' acceptance of social-media platforms, but also with their intention to use them on a continual basis. Based on these findings, our second hypothesis is formulated as follows:

H2: Users' perception of usefulness will have a positive correlation with their adoption of social-media platforms for collaborative learning.

Perceived enjoyment: Perceived enjoyment refers to the degree of enjoyment users estimate that they will receive from using social-media platforms. Initially, enjoyment is a stimulus for users' acceptance of information and communication technology in general and social-media platforms in particular. Furthermore, as a result of such enjoyment, users are naturally inclined to continue their appreciation of, support for and use of social-media platforms [41]. This was investigated by Hamid et al. [42], Demir [43] and Moghavvemi et al. [44], who found that social-media platforms that involved collaborative learning among students conducted in an interactive and enjoyable manner had a positive correlation with student acceptance. Based on these findings, the third hypothesis is established as follows:

H3: Users' perception of enjoyment will have a positive correlation with their adoption of social-media platforms for collaborative learning.

Information and resource sharing capability: Refers to the effectiveness of social-media platforms in storing and sharing necessary information and resources for education and learning, such as presentation slides for course lectures, online notebooks, electronic books and other forms of audio-visual materials connected to instruction [36, 45, 46, 47]. In this regard, Sanchez et al. [25], Milosevic et al. [27], and Sharma et al. [48] reported that information- and resource-sharing capabilities were vital determinants of the acceptance of, and support for, the use of social-media platforms for educational purposes in virtual classrooms. Based on these findings, the fourth hypothesis is developed as follows:

H4: Users' perception of information and resource sharing capability will have a positive correlation with their adoption of social media platforms for collaborative learning.

Collaborative capability: refers to the capability of social-media platforms to support collaboration among groups or online communities that share common interests, especially those related to educational purposes involving collaborative work and learning [49-53]. In their studies exploring this issue, Mazman and Usluel [36], Ractham and Firpo [45], DeAndrea et al. [54], Hung and Cheng [55] and Sharma et al. [48] similarly discovered that social-media platforms that allowed the sharing of ideas and interaction among students or classmates were likely to contribute to their adoption for collaborative learning. Yu et al. [56] and Ainin et al. [40] further found that the capability to enhance students' educational skills, including team-working skills, interpersonal relationships and intellectual abilities, were significant constructs supported by social-media platforms that lead to their adoption. Based on these findings, the fifth and final hypothesis is proposed as follows:

H5: Users' perception of collaborative capability will have a positive correlation with their adoption of social-media platforms for collaborative learning. 
Based on the literature review, the conceptual frameworks guiding the present study can be diagrammed as follows:

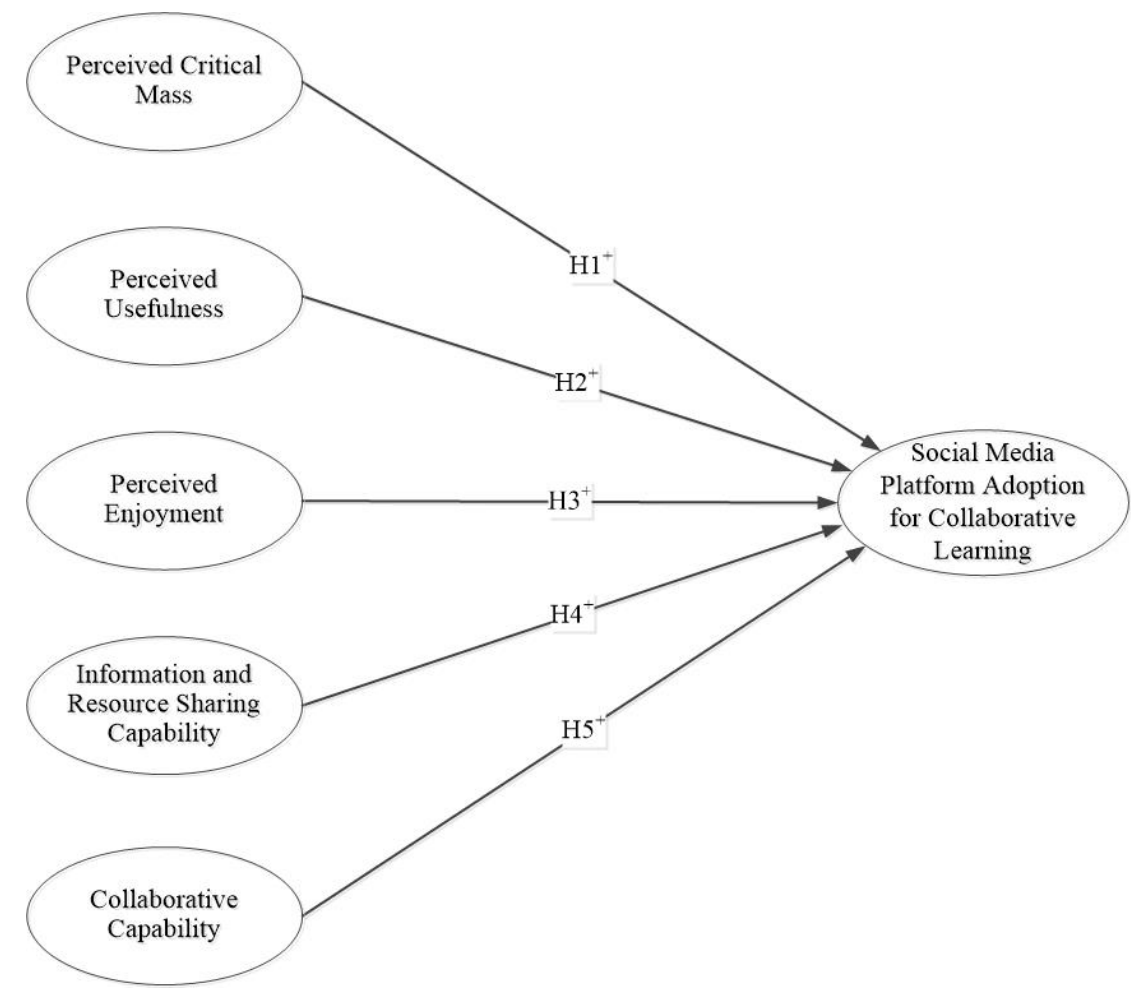

Fig. 1. Conceptual frameworks of the study

\section{$4 \quad$ Research Methods}

\subsection{Population}

The population of this research comprised university students with prior experience using social-media platforms for collaborative learning.

\subsection{Sampling technique}

The sample size was calculated from the sample-size ratio of Hair et al. [57], who postulated that a suitable sample size should be 5 to 10 times the number of indices to be measured. Because the research instrument employed in the present study was a questionnaire comprising 18 items, an ideal smallest sample size would equal to 180. Previous research studies along similar lines have recommended appropriate sample sizes (100-200) for evaluating a structural model using the partial least-squares structural equation modelling (PLS-SEM) method $[57,58,59]$. In line with such stipula- 
tions, the sample size of the present study was set to 180 . To obtain the subjects for this research, a purposive sampling technique was employed.

\subsection{Research instrument}

The research instrument was an online questionnaire comprising two sections. The first consisted of five questions related to the demographic information of the university students participating in the study. The second comprised 18 questions that addressed causal factors that influenced the subjects' adoption of social-media platforms for collaborative learning. From these, three were adapted from the works of Sanchez et al. [25], Milosevic et al. [27], Čičević et al. [26] and Ifinedo [28] to explore perceived critical-mass factors. Three were adapted from Chen and Tseng [39], Sanchez et al. [25], Ainin et al. [40] and Elkaseh et al. [35] to investigate perceived usefulness factors. Three were adapted from Hamid et al. [42], Demir [43] and Moghavvemi et al. [44] to examine perceived enjoyment factors. Three were adapted from Sanchez et al. [25], Milosevic et al. [27] and Sharma et al. [48] to survey information and resource-sharing capability factors. Three were adapted from Yu et al. [56] and Ainin et al. [40] to scrutinize collaborative capability factors. The final three were adapted from Davis [13] and Curtis et al. [14] to analyse factors related to social-media platform adoption for collaborative learning. The questionnaire were presented in a five point Likert Scale format.

\subsection{Validation of the research instrument}

The research instrument was first validated using ten subjects from the sample group to assess the comprehensibility of the questionnaire. After revisions, the questionnaire was assessed in terms of content validity by three experts using the index of item-objective congruence (IOC) scale of Rovinelli and Hambleton [60]. To ensure their consistency with our research objectives and the content to be measured, the questions used had to pass the minimum acceptable IOC score of 0.50 . The results indicated that all met the criterion with the scores ranging from 0.67 to 1.00 . Subsequently, the research instrument underwent a pilot study conducted on 30 subjects from the sample group. To ensure their reliability, the questions were required to meet the minimum acceptable Cronbach's alpha coefficient of 0.70 , following Hair et al. [57]. The results revealed that all met the standard with the scores ranging from 0.793 to 0.903 . The validation process concluded with final modifications to the research instrument.

\subsection{Data collection}

The data were collected from university students who had prior experiences in the use of social-media platforms for collaborative learning. The online questionnaire was created by using Google Forms and Google Spreadsheets, which were then circulated to the target subjects via various channels, including social-media networks (e.g., Line application, Facebook and Twitter) and e-mail platforms during August of 2020. To ensure the inclusion of only the subjects meeting the requirements of this study, the 
first demographic information question enquired as to whether or not the respondents had had any prior experience in the use of social-media platforms for collaborative learning. Those without any such experiences were excluded.

The number of questionnaires satisfying the selection criteria and eligible for further analysis was 371, which was much larger than the pre-determined sample size of 180. Then, the questionnaires returned underwent a preliminary statistical assumption test to further determine whether the responses were complete, whether there were any missing data or outliers and whether the data were normally distributed and characterized by linearity, multicollinearity and singularity. The results showed no issues surrounding these aspects. Additionally, the data were found to feature a left-skewed distribution within the range from +3 to -3 . Because the questionnaires were fit for the next stages, the data were analysed using descriptive statistics to identify the demographic characteristics of the subjects and the PLS-SEM to determine the causal relationships among the variables.

\section{$5 \quad$ Findings}

The findings are presented in two sections: 1) the demographic characteristics of the subjects and 2) the analysis of the causal relationships among the variables using the PLS-SEM.

\subsection{Section 1: Demographic characteristics of the subjects}

The majority of the subjects were female $(82.20 \%)$, followed by male $(15.90 \%)$ and LGBT (1.90\%). Two-thirds were freshmen at the time of the research $(66.80 \%)$, followed by sophomores $(21.00 \%)$, juniors $(11.60 \%)$ and seniors $(0.50 \%)$. Most had a personal monthly allowance of lower than 10,000 baht $(86.00 \%)$, followed by those earning 10,000-20,000 baht per month (12.90\%) and 20,001-30,000 baht per month $(1.10 \%)$. Almost half of the subjects spent over $5 \mathrm{~h}$ per week using the internet (46.10\%), followed by those using the internet for $11-15 \mathrm{~h}$ per week $(28.00 \%), 5-10$ $\mathrm{h}$ per week $(22.90 \%)$ and $<5 \mathrm{~h}$ per week $(3.00 \%)$. Regarding the experience in the use of social-media platforms, the most responded item was 5-7 years $(38.30 \%)$, followed by $1-5$ years $(30.20 \%),>7$ years $(24.80 \%), 1-3$ years $(5.70 \%)$ and $<1$ year $(1.10 \%)$.

\subsection{Section 2: Analysis of the causal relationships among the variables using PLS-SEM}

Assessment of the measurement model: In terms of internal consistency reliability, all latent variables in the model had a composite reliability value of over 0.708 and a Cronbach's alpha coefficient over 0.70 , demonstrating that all were reliable [61, 62]. Regarding convergent validity, all latent variables were associated with an average variance-extracted (AVE) value of higher than 0.50, indicating a satisfactory level of convergent validity between the manifest variables under the same latent variables for all latent variables constituting the model [61, 62]. Regarding indicator reliability, all manifest variables in the model were found to exhibit an outer loading coefficient 
of over 0.70 , suggesting that all were reliable $[61,62]$. The findings are displayed in Table 1 .

With regard to discriminant validity, the square root of the AVE value of each latent variable was found to be higher than the correlation coefficients between that latent variable and the other latent variables in the model. Additionally, the crossloading correlation between each manifest variable and the corresponding latent variable was the highest compared with the cross-loading correlation between each manifest variable and the other latent variables in the model. This demonstrates that all latent variables had satisfactory discriminant validity and were measured using valid manifest variables [63]. The findings are illustrated in Table 2.

Table 1. Factor loading, Cronbach's alpha, composite reliability and AVE values

\begin{tabular}{|c|c|c|c|c|c|}
\hline Constructs & Items & $\begin{array}{c}\text { Factor Loading } \\
>0.708\end{array}$ & $\begin{array}{c}\text { Cronbach's Alpha } \\
>\mathbf{0 . 7 0}\end{array}$ & $\mathrm{CR}>\mathbf{0 . 7 0}$ & $A V E>0.50$ \\
\hline \multirow{3}{*}{$\begin{array}{l}\text { Perceived critical } \\
\text { mass }(\mathrm{CM})\end{array}$} & CM1 & 0.817 & \multirow{3}{*}{0.813} & \multirow{3}{*}{0.888} & \multirow{3}{*}{0.725} \\
\hline & $\mathrm{CM} 2$ & 0.872 & & & \\
\hline & CM3 & 0.865 & & & \\
\hline \multirow{3}{*}{$\begin{array}{l}\text { Collaborative } \\
\text { capability (COL) }\end{array}$} & COL1 & 0.826 & \multirow{3}{*}{0.783} & \multirow{3}{*}{0.874} & \multirow{3}{*}{0.697} \\
\hline & $\mathrm{COL} 2$ & 0.846 & & & \\
\hline & COL3 & 0.833 & & & \\
\hline \multirow{3}{*}{$\begin{array}{l}\text { Adoption of } \\
\text { social media } \\
\text { platforms for } \\
\text { collaborative } \\
\text { learning (ITU) }\end{array}$} & ITU1 & 0.899 & \multirow{3}{*}{0.895} & \multirow{3}{*}{0.935} & \multirow{3}{*}{0.827} \\
\hline & ITU2 & 0.912 & & & \\
\hline & ITU3 & 0.916 & & & \\
\hline \multirow{3}{*}{$\begin{array}{l}\text { Information and } \\
\text { resource sharing } \\
\text { capability (MRS) }\end{array}$} & MRS1 & 0.803 & \multirow{3}{*}{0.819} & \multirow{3}{*}{0.892} & \multirow{3}{*}{0.734} \\
\hline & MRS2 & 0.888 & & & \\
\hline & MRS3 & 0.876 & & & \\
\hline \multirow{3}{*}{$\begin{array}{l}\text { Perceived enjoy- } \\
\text { ment (PE) }\end{array}$} & PE1 & 0.892 & \multirow{3}{*}{0.886} & \multirow{3}{*}{0.930} & \multirow{3}{*}{0.815} \\
\hline & PE2 & 0.918 & & & \\
\hline & PE3 & 0.897 & & & \\
\hline \multirow{3}{*}{$\begin{array}{l}\text { Perceived useful- } \\
\text { ness (PU) }\end{array}$} & PU1 & 0.847 & \multirow{3}{*}{0.786} & \multirow{3}{*}{0.876} & \multirow{3}{*}{0.701} \\
\hline & PU2 & 0.862 & & & \\
\hline & PU3 & 0.802 & & & \\
\hline
\end{tabular}


Table 2. Square roots of the AVE values of the latent variables and the correlation coefficients of the latent variables

\begin{tabular}{|c|c|c|c|c|c|c|c|}
\hline \multirow{2}{*}{ Constructs } & \multirow{2}{*}{ VIF } & \multicolumn{6}{|c|}{ Correlation Matrix } \\
\hline & & $C M$ & $C O L$ & $I T U$ & $M R S$ & $P E$ & $P U$ \\
\hline $\mathrm{CM}$ & 1.852 & 0.852 & & & & & \\
\hline $\mathrm{COL}$ & 1.644 & 0.405 & 0.835 & & & & \\
\hline ITU & 2.734 & 0.430 & 0.760 & 0.909 & & & \\
\hline MRS & 1.882 & 0.367 & 0.748 & 0.623 & 0.857 & & \\
\hline PE & 2.608 & 0.493 & 0.536 & 0.631 & 0.548 & 0.903 & \\
\hline PU & 1.720 & 0.466 & 0.652 & 0.564 & 0.607 & 0.606 & 0.837 \\
\hline
\end{tabular}

Note: The numbers in bold type along the diagonal cells were the square roots of the AVE values.

Assessment of the structural model: An assessment of a structural model requires that a multicollinearity test be conducted, the predicted variables should not bear statistically significant internal relationships, and the variance inflation factor (VIF) must be lower than $3.3[62,64]$. From Table 2, the VIF values of the predicted variables ranged from 1.644 to 2.734 , fulfilling the criteria stipulated and thus indicating no problems in terms of external construct multicollinearity.

\subsection{Hypothesis testing}

The hypotheses were tested using the PLS-SEM method by carrying out bootstrapping to evaluate the statistical significance of the parameters involved. In the present study, a two-tailed hypothesis test was conducted at the significance level of 0.05 or $p$ $<0.05$, and the $\mathrm{t}$-value was greater than or equal to 1.96 or $\mathrm{t} \geqq 1.96$, indicating confirmation of the hypotheses $[61,62,65,66,67]$. The hypothesis testing results are summarized in Table 3. 
Paper-Antecedents Influencing the Adoption of Collaborative Learning Social-Media Platforms..

Table 3. Summary of the variables and hypothesis testing

\begin{tabular}{|c|l|c|c|c|}
\hline Hypotheses & \multicolumn{1}{|c|}{ Path } & \multicolumn{1}{|c|}{$\boldsymbol{1}$} & t- values & Results \\
\hline H1 & $\begin{array}{l}\text { Perceived Critical Mass --> Social Media Platform } \\
\text { Adoption for } \\
\text { Collaborative Learning }\end{array}$ & 0.054 & 1.056 & Rejected \\
\hline H2 & $\begin{array}{l}\text { Perceived Usefulness --> Social } \\
\text { Media Platform Adoption for } \\
\text { Collaborative Learning }\end{array}$ & -0.039 & 0.743 & Rejected \\
\hline H3 & $\begin{array}{l}\text { Perceived Enjoyment --> Social } \\
\text { Media Platform Adoption for } \\
\text { Collaborative Learning }\end{array}$ & 0.303 & $5.374 * * *$ & Confirmed \\
\hline H4 & $\begin{array}{l}\text { Information and Resource Sharing Capability --> } \\
\text { Social Media Platform Adoption for Collaborative } \\
\text { Learning }\end{array}$ & 0.026 & 0.438 & Rejected \\
\hline H5 & $\begin{array}{l}\text { Collaborative Capability --> Social Media Platform } \\
\text { Adoption for } \\
\text { Collaborative Learning }\end{array}$ & 0.581 & $\begin{array}{l}10.032^{* *} \\
*\end{array}$ & Confirmed \\
\hline
\end{tabular}

*** Represents statistical significance at $p<0.001$ and $t$-value $>3.291$.

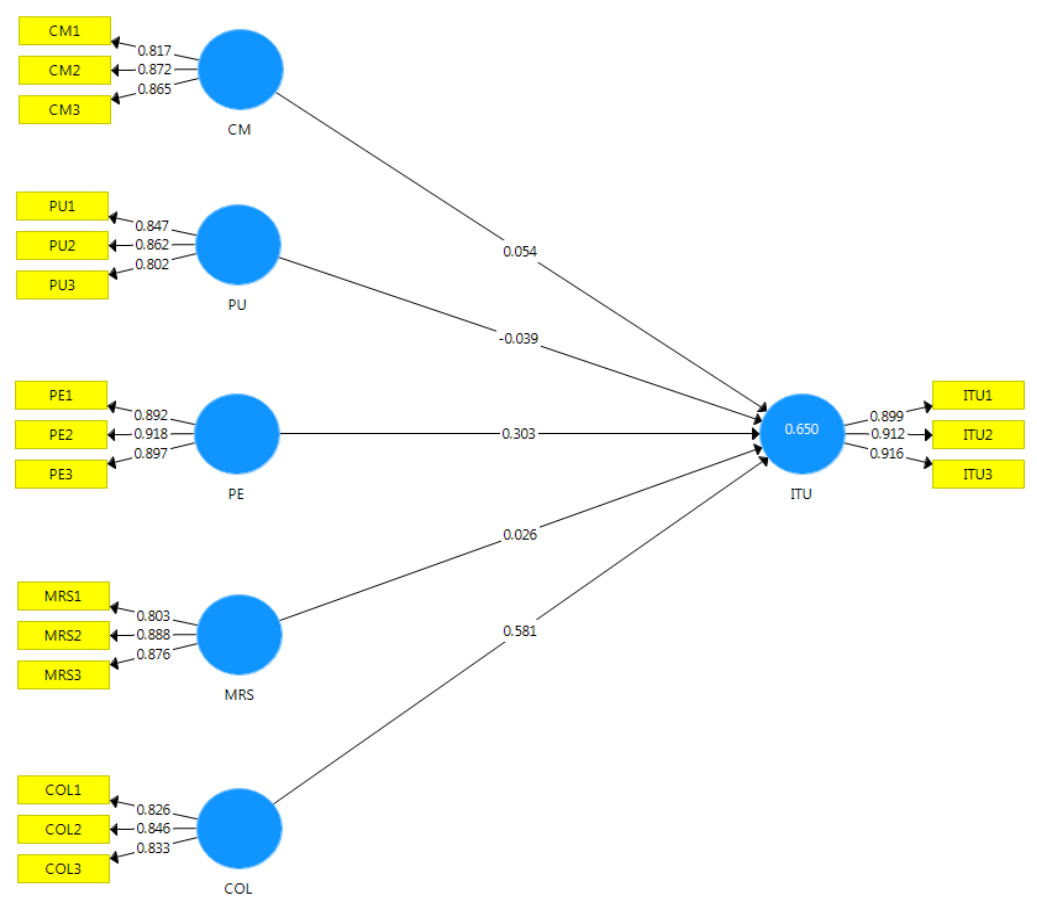

Fig. 2. Path co-efficients of the structural model 
From Table 4, the factor having the highest total effect (TE) on subjects' adoption of social-media platforms for collaborative learning was collaborative capability ( $\mathrm{TE}=0.581$ ), followed by perceived enjoyment $(\mathrm{TE}=0.303)$, perceived critical mass $(\mathrm{TE}=0.054)$, information- and resource-sharing capability $(\mathrm{TE}=0.026)$ and perceived usefulness ( $\mathrm{TE}=-0.039)$. Additionally, the factors were found to have the collective predictive power (R2) of 0.650 or $65.00 \%$ and the overall accuracy (Q2) of 0.530 (i.e., a strong correlation with one another). Finally, collaborative capability and perceived enjoyment had a direct effect (DE) on the subjects' acceptance of social-media platforms for collaborative learning at $\mathrm{DE}=0.581$ and 0.303 , respectively.

Table 4. Analysis of the path coefficients of the antecedents and the latent variables

\begin{tabular}{|c|c|c|c|c|c|c|c|c|}
\hline \multirow{2}{*}{ Latent Variables } & \multirow{2}{*}{$\mathbf{R}^{2}$} & \multirow{2}{*}{$\mathbf{Q}^{2}$} & \multirow{2}{*}{ Effects } & \multicolumn{5}{|c|}{ Antecedents } \\
\cline { 4 - 9 } & & & $\boldsymbol{C M}$ & $\boldsymbol{C O L}$ & $\boldsymbol{M R S}$ & $\boldsymbol{P E}$ & $\boldsymbol{P U}$ \\
\hline \multirow{2}{*}{$\begin{array}{l}\text { Adoption of social media } \\
\text { platforms for collabora- } \\
\text { tive learning (ITU) }\end{array}$} & \multirow{2}{*}{0.650} & 0.530 & $\mathrm{DE}$ & 0.054 & $0.581^{* * *}$ & 0.026 & $0.303^{* * *}$ & -0.039 \\
\cline { 4 - 9 } & & $\mathrm{IE}$ & 0.000 & 0.000 & 0.000 & 0.000 & 0.000 \\
\cline { 4 - 9 } & & $\mathrm{TE}$ & 0.054 & $0.581^{* * *}$ & 0.026 & $0.303^{* * *}$ & -0.039 \\
\hline
\end{tabular}

Notes:

1. *** Represents statistical significance at $p<0.001$.

2. $R^{2} \geqq 0.25$ indicates a low level of predictive power, $R^{2} \geqq 0.50$ indicates a moderate level of predictive power, and $R^{2} \geqq 0.0 .75$ indicates a high level of predictive power [59].

3. $Q^{2} \geqq 0.02$ indicates a low degree of correlation, $Q^{2} \geqq 0.15$ indicates a moderate degree of correlation, and $Q^{2} \geqq 0.35$ indicates a high degree of correlation [59].

\section{Discussion}

The findings reported in this research demonstrate that collaborative capability and perceived enjoyment are likely to be the most powerful causal factors influencing university students' adoption of social-media platforms for collaborative learning during the COVID-19 'new normal' era. Additionally, the results suggest that collaborative capability and perceived enjoyment exert a direct effect on university students' adoption of the platforms. Overall, this reflects their perception of social-media platforms as useful tools for group work, class discussions and information sharing, regardless of space and time constraints, thereby engendering their adoption of such learning aids for interaction with their classmates and instructors.

The inferences relating to collaborative capability are in line with those found by Habibi et al. [51], Rimor and Arie [52] and Ibrahim et al. [53], all of whom concluded that the capability of social-media platforms to create virtual groups positively correlated with users' adoption for educational purposes. Similar implications were also found by Ainin et al. [40] and Sharma et al. [48], who concurred that social-media platforms that effectively enabled collaboration via group discussions, information sharing and real-time interaction were likely to increase user's adoption for collaborative learning. 
Regarding perceived enjoyment, it is possible to attribute user adoption of socialmedia platforms for collaborative learning to the feeling of entertainment experienced during the course of use, particularly in terms of the broad array of services offered, such as games, puzzles, surveys and clip sharing. In fact, this claim is corroborated by a great deal of research. Hamid et al. [42], Demir [43] and Moghavvemi et al. [44], among others, reasoned from their findings that the enjoyment obtained from using social-media platforms for learning differed markedly from that of traditional classrooms and was found to be a significant factor influencing university students' adoption for collaborative learning.

Although collaborative capability and perceived enjoyment prove to be significant factors, it is interesting to find that the significance of perceived critical mass, perceived usefulness and information- and resource-sharing capability are less distinct. In other words, the extents to which university students are affected by their influencers, perceive the usefulness of social media platforms in enhancing their collaborative learning experience and construe the capability of such platforms to help them share information and resources through electronic means do not seem to be powerful predictors of their adoption of technology. Despite being contrary to expectations, such a phenomenon can be explained from a consumer-behaviour perspective. That is, the current generation of university students, or the so-called 'Generation Z', is often characterized as being technologically savvy. Thus, it is possible that factors relating to perceived critical mass, perceived usefulness and information- and resource-sharing capability may not come across as genuinely advantageous to these digital natives. In support of this postulation are a myriad of studies that similarly reached conclusions stating that users' adoption of social-media platforms for collaborative learning was not likely to be attributable to perceived critical mass $[68,69]$, perceived usefulness $[70,71,72]$, or information- and resource-sharing capability [72, 73, 74].

\section{$7 \quad$ Recommendations}

Based on the findings reported in this research, recommendations can be made as follows.

\subsection{Theories}

This research developed a model describing the causal factors influencing university students' adoption of social-media platforms for collaborative learning during the COVID-19 'new normal' era, applying Davis's [13] TAM and Curtis et al.'s [14] UTAUT to establish conceptual framework. The present findings are consistent with those discovered by previous studies, demonstrating that collaborative capability and perceived enjoyment are probably the two most significant causal factors. However, the roles of perceived critical mass, perceived usefulness and information- and resource-sharing capability remain unclear. Although the results reported in this research may seem to contradict the theories postulating the significance of such factors, it is premature to conclude that they have no role to play. Additionally, the col- 
lective predictive power $\left(\mathrm{R}^{2}\right)$ of collaborative capability and perceived enjoyment stood at $65.00 \%$. To put it in other words, other factors should exist to account for the remaining $35.00 \%$. Thus, any comprehensive theories relating to the adoption of social-media platforms for collaborative learning are likely to identify such missing pieces.

\subsection{Applications}

Based on the findings regarding the most influential factors affecting users' adoption of social-media platforms for collaborative learning, tertiary institutions, instructors and all other relevant parties should develop instructional management systems that effectively incorporate such online instruction channels as social media platforms to allow students to collaborate, exchange ideas, share experiences and interact both with one another and with their instructors. Moreover, an effort should be made to create an enjoyable environment that integrates non-traditional instructional activities, including online surveys, games, video clips and group projects. These suggestions would result in a learning atmosphere that is more in line with the present and future educational trends that people/learners seem to attach less importance to face-to-faceclassroom interaction, and more to education freed from place and time constraints. Ultimately, students will be motivated to engage in activities for their personal learning goals such as academic, professional and personal development goals. A range of applications are considered as effective tools for the current 'new normal' era.

\subsection{Further research}

1. Future research along similar lines should employ a mixed approach that incorporates both quantitative and qualitative methods, such as interviews and focus-group discussions, in order to enrich the current understanding of issues surrounding users' adoption of social-media platforms for collaborative learning and to triangulate the findings.

2. Future research should also examine other causal factors likely to have an effect on users' adoption of technology for collaborative learning, such as interactional capability, perceived ability to use technology and perceived social identity.

3. Future research may apply the conceptual framework presented in this study or one of those employed in the literature to examine users' adoption of other types of platforms or educational technology in Thailand.

\section{References}

[1] The Medical Council of Thailand. (2020). Interesting facts about COVID-19 infectious disease from SARS-CoV-2 virus. Retrieved July 3, 2020 from https://tmc.or.th/covid19/ download/pdf/tmc-covid19-19.pdf

[2] Royal Thai Government. (2020). Current news on Covid-19]. Retrieved July 3, 2020 from https://www.thaigov.go.th/news/contents/details/27963 
[3] Boonsiripunth, M. (2020). What is 'New Normal'? Retrieved July 3, 2020 from https:// www.bangkokbiznews.com/news/detail/882508

[4] Bangkokbiznews.com. (2020). What is 'New Normal'? When COVID-19 pushes us into a new normal life]. Retrieved July 3, 2020 from https://www.bangkokbiznews.com/news/ detail/882508

[5] Ibid.

[6] Pittayapongsakorn, N. (2020). What is the new normal of Thai education? When distance learning is not the answer. Retrieved July 3, 2020 from https://tdri.or.th/2020/05/desirablenew-normal-for-thailand-education/

[7] Anuradha, A.G. (1995). Collaborative Learning Enhances Critical Thinking. Journal of Technology Education, 7(1): 22-30. https://doi.org/10.21061/jte.v7i1.a.2

[8] Gao, F., Luo, T., Zhang, K. (2012). Tweeting for learning: a critical analysis of research on microblogging in education published in 2008-2011. British Journal of Educational Technology, 43(5): 783-801. https://doi.org/10.1111/j.1467-8535.2012.01357.x

[9] Tess, P.A. (2013). The role of social media in higher education classes (real and virtual) a literature review. Computers in Human Behavior, 9(5): 60-68. http://dx.doi.org/10.1016/ j.chb.2012.12.032

[10] Manca, S., Ranieri, M. (2017). Networked scholarship and motivations for social media use in scholarly communication. The International Review of Research in Open and Distributed Learning, 18(2): 123-138. https://doi.org/10.19173/irrodl.v18i2.2859

[11] Rodríguez-Hoyos, C., Haya, I., Fernández-Díaz, E. (2015). Research on SNS and education: the state of the art and its challenges. Australasian Journal of Educational Technology, 31(1): 100-111. https://doi.org/10.14742/ajet.995

[12] Hew, K.F. (2011). Students' and teachers' use of Facebook. Computers in Human Behavior, 27(2): 662-676. https://doi.org/10.1016/j.chb.2010.11.020

[13] Davis, F.D. (1989). Perceived usefulness, perceived ease of use, and user acceptance of information technology. MIS Quarterly, 13(3): 319-340. https://doi.org/10.2307/249008

[14] Curtis, L., Edwards, C., Fraser, K.L., Gudelsky, S., Holmquist, J., Thornton, K., Sweetser, K.D. (2010). Adoption of social media for public relations by nonprofit organizations. Public Relations Review, 36(1): 90-92. https://doi.org/10.1016/j.pubrev.2009.10.003

[15] Fishbein, M., Ajzen, A. (1975). Beliefs, attitudes, intentions, and behavior: An introduction to theory and research. Reading, MA: Addison-Wesley.

[16] Venkatesh, V., Morris, M.G., Davis, G.B., Davis, F.D. (2003). User Acceptance of Information Technology: Toward a Unified View. MIS Quarterly, 27(3): 425-478. https://doi. org $/ 10.2307 / 30036540$

[17] Lin, C.P., Anol, B. (2008). Learning online social support: An investigation of network information technology based on UTAUT. Cyber psychology and Behavior, 11(3): 268-272. http://doi.org/10.1089/cpb.2007.0057

[18] Nuq, P.A., Aubert, B. (2013). Towards a better understanding of the intention to use eHealth services by medical professionals: The case of developing countries, International Journal of Healthcare Management, 6(4): 217-236. https://doi.org/10.1179/2047971913Y. $\underline{0000000033}$

[19] Sweeney, J.C., Soutar, G.N, Mazzarol, T. (2008). Factors influencing word of mouth effectiveness: receiver perspectives. European Journal of Marketing, 42(3/4): 344-364. https:// doi.org/10.1108/03090560810852977

[20] Chu, S.C., Kim, Y. (2011). Determinants of Consumer Engagement in Electronic Word-ofMouth (EWOM) in Social Networking Sites. International Journal of Advertising, 30(1): 47-75. https://doi.org/10.2501/IJA-30-1-047-075 
[21] Rauniar, R., Rawski, G., Yang, J., Johnson, B. (2014). Technology acceptance model (TAM) and social media usage: an empirical study on Facebook. Journal of Enterprise Information Management, 27(1): 6-30. https://doi.org/10.1108/JEIM-04-2012-0011

[22] Coulter, K.S., Roggeveen, A. (2012). "Like it or not" : Consumer responses to word of - mouth communication in on - line social networks. Management Research Review, 35(9): 878-899. https://doi.org/10.1108/01409171211256587

[23] Chen, H.-L., Fan, H.-L., Tsai, C.-C. (2014). The Role of Community Trust and Altruism in Knowledge Sharing: An Investigation of a Virtual Community of Teacher Professionals. Journal of Educational Technology \& Society, 17(3): 168-179.

[24] Baborska-Narozny, M., Stirling, E., Stevenson, F. (2017). Exploring the Efficacy of Facebook Groups for Collective Occupant Learning About Using Their Homes. American Behavioral Scientist, 61(7): 757-773. https://doi.org/10.1177/0002764217717566

[25] Sánchez, R.A., Cortijo, V., Javed, U. (2014). Students' perceptions of Facebook for academic purposes. Computers \& Education, 70: 138-149. https://doi.org/10.1016/j.compedu. 2013.08.012

[26] Čičević, S., Samčović, A., Nešić, M. (2016). Exploring college students' generational differences in Facebook usage. Computers in Human Behavior, 56: 83-92.

[27] Milosevic, I., Zivkovic, D., Arsic, S., Manasijevic, D. (2015). Facebook as virtual classroom: eSocial networking in learning and teaching among Serbian students. Telematics and Informatics, 32(4): 576-585.

[28] Ifinedo, P. (2016). Applying uses and gratifications theory and social influence processes to understand students' pervasive adoption of social networking sites: perspectives from the Americas. International Journal of Information Management, 36(2): 192-206. https:// doi.org/10.1016/j.ijinfomgt.2015.11.007

[29] Park, N., Rhoads, M., Hou, J., Lee, K. M. (2014). Understanding the acceptance of teleconferencing systems among employees: An extension of the technology acceptance model. Computers in Human Behavior, 39: 118-127. https://doi.org/10.1016/j.chb.2014.05.048

[30] Kim, J.S. (2016). An extended technology acceptance model in behavioral intention toward hotel tablet apps with moderating effects of gender and age. International Journal of Contemporary Hospitality Management, 28: 1535-1553.

[31] Lee, M.C. (2009). Factors influencing the adoption of internet banking: An integration of TAM and TPB with perceived risk and perceived benefit. Electronic Commerce Research and Applications, 8: 130-141. https://doi.org/10.1016/j.elerap.2008.11.006

[32] Kang, Y.S., Lee, H. (2010). Understanding the role of an IT artefact in online service continuance: An extended perspective of user satisfaction. Computers in Human Behaviour, 26: 353-364. https://doi.org/10.1016/j.chb.2009.11.006

[33] Jan, A. U., Contreras, V. (2011). Technology acceptance model for the use of information technology in universities. Computers in Human Behavior, 27: 845-851. https://doi.org/10. 1016/j.chb.2010.11.009

[34] Merhi, M.I. (2015). Factors influencing higher education students to adopt podcast: an empirical study. Computers \& Education, 83:32-43. https://doi.org/10.1016/j.compedu.2014 .12 .014

[35] Elkaseh, A.M., Wong, K.W., Fung, C.C. (2016). Perceived ease of use and perceived usefulness of social media for e-learning in Libyan higher education: a structural equation modeling analysis. International Journal of Information and Education Technology, 6(3): 192-199. https://doi.org/10.7763/IJIET.2016.V6.683

[36] Mazman, S.G., Usluel, Y.K. (2010). Modeling Educational Usage of Facebook. Computers \& Education, 55(2): 444-453. https://doi.org/10.1016/j.compedu.2010.02.008 
[37] Lin, X., Li, Y., Califf, C.B., Featherman, M. (2013). Can social role theory explain gender differences in Facebook usage? Proceedings of the $46^{\text {th }}$ IEEE Hawaii International Conference in System Sciences (HICSS), 7-10 January 2013, pp. 690-699. https://doi.org/10. 1109/HICSS.2013.125

[38] Lee, C.E.C., Chong, A.Y.W. (2017). Students' adoption of Facebook in higher education: a gender-based comparison. Proceedings of the International Conference on Communication and Media: An International Communication Association Regional Conference (i-COME'16), 02 February 2017, pp. 1-6. https://doi.org/10.1051/shsconf/20173300010

[39] Chen, H.R., Tseng, H.F. (2012). Factors that influence acceptance of web-based e-learning systems for the in-service education of junior high school teachers in Taiwan. Evaluation and Program Planning, 35(3): 398-406. https://doi.org/10.1016/j.evalprogplan.2011.11.007

[40] Ainin, S., Naqshbandi, M.M., Mogavvemi, S., Jaafar, N.I. (2015). Facebook usage, socialization and academic performance. Computers \& Education, 83: 64-73. https://doi.org/10.1016/j.compedu.2014.12.018

[41] Kim, B.G., Park, S.C., Lee, K.J. (2007). A structural equation modeling of the Internet acceptance in Korea. Electronic Commerce Research and Applications, 6(4): 425-432. http://doi.org/10.1016/j.elerap.2006.08.005

[42] Hamid, S., Waycott, J., Kurnia, S., Chang, S. (2015). Understanding students' perceptions of the benefits of online social networking use for teaching and learning. The Internet and Higher Education, 26: 1-9. https://doi.org/10.1016/j.iheduc.2015.02.004

[43] Demir, M. (2018). Using online peer assessment in an instructional technology and material design course through social media. Higher Education, 75: 399-414. https://doi.org/10 $.1007 / \mathrm{s} 10734-020-00505-6$

[44] Moghavvemi, S., Paramanathan, T., Rahin, N.M., Sharabati, M. (2017). Student's perceptions towards using e-learning via Facebook. Behaviour \& Information Technology, 36(10): 1081-1100. https://doi.org/10.1080/0144929X.2017.1347201

[45] Ractham, P., Firpo, D. (2011). Using social networking technology to enhance learning in higher education: a case study using Facebook. Proceedings of the IEEE $44^{\text {th }}$ Hawaii International Conference on System Sciences (HICSS), 4-7 January 2011, pp. 1-10. https:// doi.org/10.1109/HICSS.2011.479

[46] Bicen, H., Uzunboylu, H. (2013). The use of social networking sites in education: a case study of Facebook. Journal of Universal Computer Science, 19(5): 658-671. https://doi. org/10.3217/jucs-019-05-0658

[47] Lambić, D. (2016). Correlation between Facebook use for educational purposes and academic performance of students. Computers in Human Behaviour, 61: 313-320. https://doi. org/10.1016/j.chb.2016.03.052

[48] Sharma, S.K., Joshi, A., Sharma, H. (2016). A multi-analytical approach to predict the Facebook usage in higher education. Computers in Human Behaviour, 55: 340-353. https:// doi.org/10.1016/j.chb.2015.09.020

[49] Selwyn, N. (2007). 'Screw Blackboard... do it on Facebook!': an investigation of students' educational use of Facebook. Retrieved July 3, 2020 from https://www.scribd.com/doc/51 3958/Facebook-seminar-paper-Selwyn

[50] Zheng, X., Cheung, C.M., Lee, M.K., Liang, L. (2015). Building brand loyalty through user engagement in online brand communities in social networking sites. Information Technology \& People, 28(1): 90-106. https://doi.org/10.1108/ITP-08-2013-0144

[51] Habibi, M.R., Laroche, M., Richard, M.O. (2016). Testing an extended model of consumer behavior in the context of social media-based brand communities. Computers in Human Behavior, 62: 292-302. https://doi.org/10.1016/j.chb.2016.03.079 
[52] Rimor, R., Arie, P. (2016). Visit to a small planet': achievements and attitudes of high school students towards learning on Facebook - a case study. Handbook of Research on Technology Tools for Real-World Skill Development, IGI Global: 528-557. https://doi.org/10.4018/978-1-4666-9441-5.ch020

[53] Ibrahim, N.F., Wang, X., Bourne, H. (2017). Exploring the effect of user engagement in online brand communities: evidence from Twitter. Computers in Human Behavior, 72: 321-338. https://doi.org/10.1016/j.chb.2017.03.005

[54] DeAndrea, D.C., Ellison, N.B., LaRose, R., Steinfield, C., Fiore, A. (2012). Serious social media: on the use of social media for improving students' adjustment to college. The Internet and Higher Education, 15(1): 15-23. https://doi.org/10.1016/j.iheduc.2011.05.009

[55] Hung, S.W., Cheng, M.J. (2013). Are you ready for knowledge sharing? An empirical study of virtual communities. Computers \& Education, 62: 8-17. https://doi.org/10.10 16/j.compedu.2012.09.017

[56] Yu, A.Y., Tian, S.W., Vogel, D., Kwok, R.C.W. (2010). Can learning be virtually boosted? An investigation of online social networking impacts. Computers \& Education, 55(4): 1494-1503. https://doi.org/10.1016/j.compedu.2010.06.015

[57] Hair, J.F., Black, W.C., Babin, B.J., Anderson, R.E. (2010). Multivariate data analysis ( $7^{\text {th }}$ ed.). Englewood Cliffs: Prentice Hall.

[58] Ringle, C.M., Götz, O., Wetzels, M., Wilson, B. (2009). On the use of formative measurement specifications in structural equation modeling: A Monte Carlo simulation study to compare covariance-based and partial least squares model estimation methodologies. In METEOR Research Memoranda (RM/09/014): Maastricht University. https://doi.org/10. 26481/umamet.2009014

[59] Hair, J.F., Hult, G.T.M., Ringle, C.M., Sarstedt, M. (2014). A Primer on Partial Least Squares Structural Equation Modeling (PLS-SEM). California, CA: Sage Publications.

[60] Rovinelli, R.J., Hambleton, R.K. (1977). On the use of content specialists in the assessment of criterion-referenced test item validity. Dutch Journal of Educational Research, 2: 49-60.

[61] Chin, W.W. (2010). How to write up and report PLS analyses, in Esposito Vinzi, V., Chin, W.W., Henseler, J. and Wang, H. (Eds), Handbook of Partial Least Squares: Concepts, Methods and Applications, Vol. 2, Springer Handbooks of Computational Statistics Series. Springer, Heidelberg: 655-690. https://doi.org/10.1007/978-3-540-32827-8

[62] Hair, J.F, Hult, G.T.M., Ringle, C.M., Sarstedt, M. (2017). A Primer on Partial Least Squares Structural Equation Modeling (PLS-SEM). $2^{\text {nd }}$ ed. Thousand Oaks, CA: Sage.

[63] Fornell, C., Larcker, D.F. (1981). Evaluating Structural Equation Models with Unobservable Variables and Measurement Error. Journal of Marketing Research, 18(1): 39-50. https://doi.org/10.1177/002224378101800104

[64] Diamantopoulos, A., Siguaw, J.A. (2006). Formative vs reflective indicators in measure development: does the choice of indicators matter? British Journal of Management. 13(4): 263-282. https://doi.org/10.1111/j.1467-8551.2006.00500.x

[65] Helm, S., Eggert, A., Garnefeld, I. (2010). Modeling the Impact of Corporate Reputation on Customer Satisfaction and Loyalty Using Partial Least Squares. In: Esposito Vinzi V., Chin W., Henseler J., Wang H. (eds) Handbook of Partial Least Squares. Springer Handbooks of Computational Statistics. Springer, Berlin, Heidelberg. https://doi.org/10.1007/9 78-3-540-32827-8_23

[66] Henseler, J., Sarstedt, M. (2013). Goodness-of-fit indices for partial least squares path modeling. Computational Statistics, 28(2): 565-580. https://doi.org/10.1007/s00180-012$\underline{0317-1}$ 
[67] Wong, K.K.K. (2013). Partial least squares structural equation modeling (PLS-SEM) techniques using SmartPLS. Marketing Bulletin, 24(1): 1-32. http://marketing-bulletin.mas sey.ac.nz/V24/MB_V24_T1_Wong.pdf

[68] Owusu, G.M.Y., Bekoe, R.A., Otoo, D.S., Koli, A.P.E. (2019). Adoption of social networking sites for educational use. Journal of Applied Research in Higher Education, 11(1): 2-19. https://doi.org/10.1108/JARHE-04-2018-0069

[69] Rahman, N.S.A, Handayani, L., Othman, M.S., Al-Rahmi, W.M., Kasim, S., Sutikno, T. (2020). Social media for collaborative learning. International Journal of Electrical and Computer Engineering (IJECE), 10(1): 1070-1078. https://doi.org/10.11591/ijece.v10i1.pp $\underline{1070-1078}$

[70] Pinho, J.C.M.R., Soares, A.M. (2011). Examining the technology acceptance model in the adoption of social networks. Journal of Research in Interactive Marketing, 5(2/3): 116-129. https://doi.org/10.1108/17505931111187767

[71] Setiawan, R.A., Setyohadi, D.B., Pranowo, P. (2018). Understanding customers' intention to use social network sites as complaint channel: An analysis of young customers' perspectives. E3S Web of Conferences, 31: 1-17. https://doi.org/10.1051/e3sconf/20183111014

[72] Lin J.-W., Lin K.H.-C. (2019). User acceptance in a computer-supported collaborative learning (CSCL) environment with social network awareness (SNA) support. Australasian Journal of Educational Technology, 35(1): 100-115. https://doi.org/10.14742/ajet.3395

[73] Murire, O.T., Cilliers, L. (2017). Social media adoption among lecturers at a traditional university in Eastern Cape Province of South Africa. South African Journal of Information Management, 19(1): a834. https://doi.org/10.4102/sajim.v19i1.834

[74] Nawi, N.C., Al Mamun, A., Nasir, N.A.M., Muniady, R. (2019). Factors Affecting the Adoption of Social Media as a Business Platform: A Study among Student Entrepreneurs in Malaysia. Vision, 23(1): 1-11. https://doi.org/10.1177/0972262918821200

[75] Laal, M., Ghodsi, S. M. (2012). Benefits of collaborative learning. Procedia-social and behavioral sciences, 31: 486-490. https://doi.org/10.1016/j.sbspro.2011.12.091

[76] Shih, Y. C., Yang, M. T. (2008). A collaborative virtual environment for situated language learning using VEC3D. Educational Technology \& Society, 11(1): 56-68.

[77] Khadka, R., Money, J. H., Banic, A. (2018). Evaluation of scientific workflow effectiveness for a distributed multi-user multi-platform support system for collaborative visualization. Proceedings of the Practice and Experience on Advanced Research Computing, 22-26 July 2018, pp.1-8. https://doi.org/10.1145/3219104.3229283

[78] Anderson, T. (2004). Teaching in an online learning context. In T. Anderson, \& F. Elloumi (Eds.), Theory and practice of online learning (pp. 273-294). Athabasca: Athabasca University.

\section{$9 \quad$ Author}

Thadathibesra Phuthong is lecturer in the department of exhibition and event management, Faculty of Management Science, Silpakorn University, Thailand. He graduated from Thammasat Business School, Thailand in Management Information Systems. His current research interests include technology innovation management, digital entrepreneurship, social commerce, online learning tools, and collaboration tools.

Article submitted 2020-08-27. Resubmitted 2021-03-24. Final acceptance 2021-03-24. Final version published as submitted by the authors. 